\title{
Risk of colorectal cancer among immigrants to Ontario, Canada
}

\author{
Lawrence Paszat $^{1 *}$, Rinku Sutradhar ${ }^{1}$, Ying Liư ${ }^{1}$, Nancy N. Baxter ${ }^{2}$, Jill Tinmouth ${ }^{3}$ and Linda Rabeneck ${ }^{4}$
}

\begin{abstract}
Background: The risk of colorectal cancer (CRC) varies around the world and between females and males. We aimed to compare the risk of CRC among immigrants to Ontario, Canada, to its general population.

Methods: We used an exposure-control matched design. We identified persons in the Immigration, Refugees and Citizenship Canada Permanent Resident Database with first eligibility for the Ontario Health Insurance Plan between July 1, 1991 and June 30, 2008 at age 40 years or older, and matched five controls by year of birth and sex on the immigrant's first eligibility date. We identified CRC from the Ontario Cancer Registry between the index date and December 31, 2014. All analyses were stratified by sex. We calculated crude and relative rates of CRC. We estimated risk of CRC over time by the Kaplan-Meier method and compared immigrants to controls in age and sex stratified strata using log-rank tests. We modeled the hazard of CRC using Cox proportional hazards regression, accounting for within-cluster correlation by a robust sandwich variance estimation approach, and assessed an interaction with time since eligibility.

Results: Among females, 1877 cases of CRC were observed among 209,843 immigrants, and 16,517 cases among $1,049,215$ controls; the crude relative rate among female immigrants was 0.623 . Among males, 1956 cases of CRC were observed among 191,792 immigrants and 18,329 cases among 958,960 controls; the crude relative rate among male immigrants was 0.582.. Comparing immigrants to controls in all age and sex stratified strata, the log rank test $p<0.0001$ except for females aged $>=75$ years at index, where $p=0.01$. The age-adjusted hazard ratio (HR) for CRC among female immigrants was 0.63 (95\% Cl 0.59, 0.67) during the first 10 years, and 0.66 ( $95 \% \mathrm{Cl} 0.59$, $0.74)$ thereafter. Among male immigrants the age-adjusted $\mathrm{HR}=0.55(95 \% \mathrm{Cl} 0.52,0.59)$ during the first 10 years and increased to $0.63(95 \% \mathrm{Cl} 0.57,0.71)$ thereafter. The adjusted HR > = 1 only among immigrants born in Europe and Central Asia.
\end{abstract}

Conclusions: The risk of CRC among immigrants to Ontario relative to controls varies by origin and over time since immigration.

Keywords: Colorectal cancer, Cancer registry, Immigrants, Exposure-control matched design, Cox proprotional hazards regression

\section{Background}

The incidence of CRC varies between males and females, among individual nations and regions of the world, and is associated with environmental, behavioural and genetic factors [1-3]. Among nations with previously lower incidence and current adoption of Western lifestyles, the incidence is increasing [4-7], although India is a notable example of an exception to this trend [8]. This trend has

\footnotetext{
* Correspondence: lawrence.paszat@ices.on.ca

'University of Toronto, Institute for Clinical Evaluative Sciences, G106 2075

Bayview Avenue, Toronto, ON M4N3M5, Canada

Full list of author information is available at the end of the article
}

also been described among immigrants to California from previously lower incidence nations [9].

The incidence of CRC has been high in Canada compared to most other countries. Crude and world age standardized CRC incidence for Canada in 2012 are 68.5 and 35.2 per 100,000 respectively, compared to 50.7 and 27.0 per 100,000 respectively for Poland, 18.6 and 14.2 per 100,000 respectively for China, and 5.1 and 6.1 per 100,000 for India [10]. Lower risk of CRC among immigrants compared to non-immigrant populations with 
Table 1 Description of immigrants and controls

\begin{tabular}{|c|c|}
\hline Females & Immigrants \\
\hline \multicolumn{2}{|l|}{ Overall count } \\
\hline Overall count & 209,843 \\
\hline \multicolumn{2}{|l|}{ Year of index date } \\
\hline $1991-1995$ & $59,210(28.2 \%)$ \\
\hline $1996-2000$ & $53,063(25.3 \%)$ \\
\hline $2001-2005$ & $64,922(30.9 \%)$ \\
\hline $2006-2008$ & $32,648(15.6 \%)$ \\
\hline \multicolumn{2}{|c|}{ Person years by year of index date } \\
\hline $1991-1995$ & 940,939 person-years \\
\hline $1996-2000$ & 725,818 person-years \\
\hline $2001-2005$ & 646,525 person-years \\
\hline $2006-2008$ & 225,685 person-years \\
\hline \multicolumn{2}{|c|}{ Followup time by year of index date } \\
\hline \multicolumn{2}{|l|}{$1991-1995$} \\
\hline Mean (SD) & 15.89 years $(7.59)$ \\
\hline Median (IQR) & 19.76 years $(9.88-21.55)$ \\
\hline \multicolumn{2}{|l|}{$1996-2000$} \\
\hline Mean (SD) & 13.68 years $(5.18)$ \\
\hline Median (IQR) & 15.40 years $(13.08-17.27$ \\
\hline \multicolumn{2}{|l|}{$2001-2005$} \\
\hline Mean (SD) & 9.96 years $(3.48)$ \\
\hline Median (IQR) & $10.84(9.24-12.43)$ \\
\hline \multicolumn{2}{|l|}{$2006-2008$} \\
\hline Mean (SD) & 6.91 years $(2.09)$ \\
\hline Median (IQR) & 7.44 years $(6.71-8.27)$ \\
\hline \multicolumn{2}{|l|}{ Age at index date } \\
\hline 40 - 49 years & $97,829(46.6 \%)$ \\
\hline 50 - 59 years & $51,806(24.7 \%)$ \\
\hline 60 - 69 years & $41,029(19.6 \%)$ \\
\hline $70-74$ years & $10,342(4.9 \%)$ \\
\hline$>=75$ years & $8837(4.2 \%)$ \\
\hline
\end{tabular}

Person years by age at index date

$\begin{array}{lll}40-49 \text { years } & 1,235,292 \text { person-years } & 6,646,937 \text { person-years } \\ 50 \text { - 59 years } & 664,305 \text { person-years } & 3,624,482 \text { person-years } \\ 60 \text { - } 69 \text { years } & 470,317 \text { person-years } & 2,700,938 \text { person-years } \\ 70-74 \text { years } & 100,008 \text { person-years } & 578,455 \text { person-years } \\ >=75 \text { years } & 69,043.82 \text { person-years } & 367,123.65 \text { person-years }\end{array}$

Followup time by age at index date

$\begin{array}{lll}40 \text { - } 49 \text { years } & & \\ \text { Mean (SD) } & 12.63 \text { years }(5.78) & 13.59 \text { years }(5.25) \\ \text { Median (IQR) } & 12.34 \text { years }(8.44-17.27) & 13.17 \text { years }(9.37-17.83) \\ 50 \text { - } 59 \text { years } & & \\ \text { Mean (SD) } & 12.82 \text { years }(6.24) & 13.97 \text { years }(5.56) \\ \text { Median (IQR) } & 12.63 \text { years }(8.25-18.24) & 13.56 \text { years }(9.39-18.82)\end{array}$

10.77 years $(2.62)$

11.19 years $(9.78-12.56)$

7.43 years $(1.45)$

7.64 years $(7.02-8.35)$

$489,110(46.6 \%)$

$259,489(24.7 \%)$

$204,985(19.5 \%)$

$51,447(4.9 \%)$

$44,184(4.2 \%)$
Table 1 Description of immigrants and controls (Continued)

\begin{tabular}{|c|c|c|}
\hline \multicolumn{3}{|l|}{$60-69$ years } \\
\hline Mean (SD) & 11.46 years $(6.46)$ & 13.18 years $(5.70)$ \\
\hline Median (IQR) & 11.42 years $(6.87-16.66)$ & 12.90 years $(8.72-17.86)$ \\
\hline \multicolumn{3}{|l|}{$70-74$ years } \\
\hline Mean (SD) & 9.67 years $(6.16)$ & 11.24 years $(5.53)$ \\
\hline Median (IQR) & 9.32 years $(4.57-14.15)$ & 10.98 years $(7.30-15.17)$ \\
\hline \multicolumn{3}{|l|}{$>=75$ years } \\
\hline Mean (SD) & 7.81 years $(5.28)$ & 8.31 years $(5.04)$ \\
\hline Median (IQR) & 7.34 years $(3.39-11.48)$ & 7.89 years $(4.30-11.70)$ \\
\hline Males & Immigrants & Controls \\
\hline Overall count & 191,792 & 958,960 \\
\hline \multicolumn{3}{|l|}{ Year of index date } \\
\hline $1991-1995$ & $48,793(25.4 \%)$ & $243,965(25.4 \%)$ \\
\hline $1996-2000$ & $51,328(26.8 \%)$ & $256,640(26.8 \%)$ \\
\hline $2001-2005$ & $62,371(32.5 \%)$ & $311,855(32.5 \%)$ \\
\hline $2006-2008$ & $29,300(15.3 \%)$ & $146,500(15.3 \%)$ \\
\hline \multicolumn{3}{|c|}{ Person years by year of index date } \\
\hline $1991-1995$ & 744,331 person-years & $4,121,283$ person-years \\
\hline $1996-2000$ & 685,887 person-years & $3,702,915$ person-years \\
\hline $2001-2005$ & 601,385 person-years & $3,273,836$ person-years \\
\hline $2006-2008$ & 196,843 person-years & $1,062,171$ person-years \\
\hline
\end{tabular}

Followup time by year of index date

$1991-1995$

$\begin{array}{lll}\text { Mean (SD) } & 15.25 \text { years }(7.73) & 16.89(6.58) \\ \text { Median (IQR) } & 19.45 \text { years }(8.28-21.30) & 19.78(13.12-21.56)\end{array}$

$1996-2000$

Mean (SD) $\quad 13.36$ years (5.32) $14.43(4.34)$

Median (IQR) 15.22 years (11.58 - 17.15) $15.56(14.16-17.32)$

$2001-2005$

Mean (SD) $\quad 9.64$ years (3.69) $\quad 10.50(2.88)$

Median (IQR) 10.62 years $(9.03-12.36) \quad 11.04(9.50-12.50)$

$2006-2008$

$$
\begin{array}{lll}
\text { Mean (SD) } & 6.72 \text { years }(2.26) & 7.25(1.66) \\
\text { Median (IQR) } & 7.37 \text { years }(6.58-8.24) & 7.56(6.90-8.31)
\end{array}
$$

Age at index date

$\begin{array}{lll}40-49 \text { years } & 106,112(55.3 \%) & 530,757(55.3 \%) \\ 50-59 \text { years } & 40,062(20.9 \%) & 200,563(20.9 \%) \\ 60-69 \text { years } & 31,575(16.5 \%) & 157,362(16.4 \%) \\ 70-74 \text { years } & 8070(4.2 \%) & 40,492(4.2 \%) \\ >=75 \text { years } & 5973(3.1 \%) & 29,786(3.1 \%)\end{array}$

Person years by age at index date

$\begin{array}{lll}40-49 \text { years } & 1,289,734 \text { person-years } & 7,047,301 \text { person-years } \\ 50 \text { - 59 years } & 485,469 \text { person-years } & 2,620,618 \text { person-years } \\ 60 \text { - 69 years } & 344,004 \text { person-years } & 1,886,805 \text { person-years } \\ 70-74 \text { years } & 69,618 \text { person-years } & 390,565 \text { person-years }\end{array}$


Table 1 Description of immigrants and controls (Continued)

\begin{tabular}{|c|c|c|}
\hline$>=75$ years & 39,621 person-years & 214,918 person-years \\
\hline \multicolumn{3}{|c|}{ Followup time by age at index date } \\
\hline \multicolumn{3}{|l|}{40 - 49 years } \\
\hline Mean (SD) & 12.15 years $(5.85)$ & 13.28 years $(5.23)$ \\
\hline Median (IQR) & 12.12 years $(8.09-16.70)$ & 13.09 years $(9.31-17.36)$ \\
\hline \multicolumn{3}{|l|}{50 - 59 years } \\
\hline Mean (SD) & 12.12 years $(6.11)$ & 13.07 years $(5.57)$ \\
\hline Median (IQR) & 11.90 years $(7.75-17.18)$ & 12.61 years $(8.69-17.70)$ \\
\hline \multicolumn{3}{|l|}{$60-69$ years } \\
\hline Mean (SD) & 10.89 years $(6.39)$ & 11.99 years $(5.77)$ \\
\hline Median (IQR) & 10.81 years $(6.36-15.76)$ & 11.65 years $(7.81-16.43)$ \\
\hline \multicolumn{3}{|l|}{$70-74$ years } \\
\hline Mean (SD) & 8.63 years $(5.80)$ & 9.65 years $(5.29)$ \\
\hline Median (IQR) & 8.16 years $(3.81-12.62)$ & 9.11 years $(6.09-13.08)$ \\
\hline \multicolumn{3}{|l|}{$>=75$ years } \\
\hline Mean (SD) & 6.63 years $(5.03)$ & 7.22 years (4.66) \\
\hline Median (IQR) & 6.18 years $(2.18-9.90)$ & 6.90 years $(3.39-10.31)$ \\
\hline
\end{tabular}

high prevalence of CRC has been described in Canada $[11,12]$, the USA [13], and the UK [14].

We aimed to compare the risk of CRC among immigrants to Ontario, Canada, to its general population, and to examine if the risk changed over time since arrival, stratified by world region of birth and country of birth of immigrants. Ontario recently established a CRC screening program, ColonCancerCheck (CCC), [15], consisting of biennial guaiac fecal occult blood testing (gFOBT) for persons 50 - 74 without a first degree relative affected by CRC (approximately $89 \%$ of the population of Ontario), and screening colonoscopy for those with an affected first degree relative (approximately 11\% of the population of Ontario) [16, 17]. CCC sends letters to all 50-74 year old residents of Ontario inviting them to discuss CRC screening with their primary care providers, who are supplied with gFOBT sampling kits to distribute to their eligible patients. It is already known that immigrants to Ontario are less likely to participate in colorectal screening than non-immigrants [18], as is true elsewhere in North America and Europe [19-22]. The goal of this work is to inform CCC of the risk of CRC stratified by origin of immigrants and time since immigration, so that its efforts to improve screening participation among immigrants may be tailored by this information.

\section{Methods}

This work was approved by the Research Ethics Board of Sunnybrook Health Sciences Centre and conducted at the Institute for Clinical Evaluative Sciences (ICES). We used three population-wide databases, in which each observation is identified by an encryption of the unique Ontario Health Insurance Number and are thereby linkable deterministically. The Immigration, Refugees and Citizenship Canada Permanent Resident Database (IRCC) contains the date of arrival in Canada, the intended province of residence in Canada, and the country of birth; permission to access the data was granted by the Government of Canada. The Registered Persons Database (RPDB) contains the age, sex, dates of eligiblity for the universal, single-payer Ontario Health Insurance Plan (OHIP), date of last contact with health care services in Ontario, and status on the date of last contact for each OHIP beneficiary; permission to access the data was granted by the Ministry of Health and Long Term Care of Ontario. The Ontario Cancer Registry (OCR) contains the diagnosis code for invasive cancer (International Classification of Diseases version 10) and its date of diagnosis, for all residents of Ontario diagnosed with a malignancy; permission to access the data was granted by Cancer Care Ontario.

We used an exposure-control matched design. We identified persons from the IRCC with arrival in Ontario, and whose first eligibility for OHIP fell between July 1 , 1991 and June 30, 2008 at age 40 years or older, in the Registered Persons Database (RPDB). The first eligibility date was labeled the index date for each immigrant. From the IRCC, we extracted 'country of birth' for each immigrant, and categorized 'country of birth' into a modified classification of selected world regions (East Asia and Pacific; Europe and Central Asia; Latin America and Caribbean, Middle East and North Africa, South Asia, Sub-saharan Africa) [23-25]. We matched 5 controls from the RPDB alive on the corresponding immigrant's index date and not found in the IRCC database between 1986 to 2010, on year of birth and sex.

We identified CRC (diagnosis codes C180, C182 C189, C19, C20) from the OCR among immigrants and controls between the index date and December 31, 2014. All immigrants and controls were followed to date of last contact, date of CRC diagnosis, or December 31, 2014, whichever came first.

We examined the distributions of various characteristics between immigrants and controls in the matched cohort. All analyses were stratified by sex. The crude rates of CRC (per 100,000 person-years) among immigrants and controls, along with the corresponding crude relative rate of $\mathrm{CRC}$, were calculated.

To examine the association between immigration status and the hazard of CRC, the outcome was defined as the time to diagnosis of CRC (from the index date). Individuals were censored at the time of study end or death, whichever occurred first. Kaplan Meier methods were used to graphically examine the risk of CRC over time among immigrants compared to 
Table 2 Crude rates of CRC among immigrants and controls and crude relative rate among immigrants

\begin{tabular}{|c|c|c|c|c|c|c|c|}
\hline Females & Immigrants & $\begin{array}{l}\text { CRC among } \\
\text { immigrants }\end{array}$ & Controls & $\begin{array}{l}\text { CRC among } \\
\text { controls }\end{array}$ & $\begin{array}{l}\text { Crude rate among } \\
\text { immigrants }^{a}\end{array}$ & $\begin{array}{l}\text { Crude rate } \\
\text { among } \\
\text { controls }^{a}\end{array}$ & $\begin{array}{l}\text { Crude relative } \\
\text { rate among } \\
\text { immigrants }^{a}\end{array}$ \\
\hline Overall & 209,843 & 1877 & $1,049,215$ & 16,517 & 0.203 & 0.325 & 0.623 \\
\hline \multicolumn{8}{|l|}{ Age at index date } \\
\hline $40-49$ years & $97,829(46.6 \%)$ & $442(23.5 \%)$ & $489,110(46.6 \%)$ & $3180(19.3 \%)$ & 0.098 & 0.131 & 0.748 \\
\hline 50 - 59 years & $51,806(24.7 \%)$ & $428(22.8 \%)$ & $259,489(24.7 \%)$ & $4299(26.0 \%)$ & 0.177 & 0.325 & 0.543 \\
\hline $60-69$ years & 41,029 (19.6\%) & $606(32.3 \%)$ & 204,985 (19.5\%) & $6027(36.5 \%)$ & 0.353 & 0.611 & 0.577 \\
\hline 70 - 74 years & $10,342(4.9 \%)$ & $200(10.7 \%)$ & $51,447(4.9 \%)$ & $1720(10.4 \%)$ & 0.548 & 0.815 & 0.673 \\
\hline$>=75$ years & 8837 (4.2\%) & $201(10.7 \%)$ & $44,184(4.2 \%)$ & $1291(7.8 \%)$ & 0.798 & 0.963 & 0.828 \\
\hline $\begin{array}{l}\text { Selected world regions } \\
\text { of birth }\end{array}$ & 205,469 & 1854 & $1,027,345$ & 16,217 & & & \\
\hline East Asia and Pacific & 67,385 (32.8\%) & $748(40.4 \%)$ & $336,925(32.8 \%)$ & $5771(35.6 \%)$ & 0.253 & 0.345 & 0.731 \\
\hline $\begin{array}{l}\text { Europe and Central } \\
\text { Asia }\end{array}$ & $38,315(18.7 \%)$ & $599(32.3 \%)$ & 191,575 (18.7\%) & $3107(19.2 \%)$ & 0.340 & 0.331 & 1.027 \\
\hline $\begin{array}{l}\text { Latin America and } \\
\text { the Caribbean }\end{array}$ & $23,210(11.3 \%)$ & $191(10.3 \%)$ & $116,050(11.3 \%)$ & $1789(11.0 \%)$ & 0.176 & 0.310 & 0.569 \\
\hline $\begin{array}{l}\text { Middle East and } \\
\text { North Africa }\end{array}$ & $16,222(7.9 \%)$ & $106(5.7 \%)$ & $81,110(7.9 \%)$ & $1114(6.9 \%)$ & 0.155 & 0.298 & 0.519 \\
\hline South Asia & $52,103(25.4 \%)$ & $162(8.7 \%)$ & $260,515(25.4 \%)$ & $3764(23.2 \%)$ & 0.072 & 0.308 & 0.233 \\
\hline Sub-saharan Africa & 8234 (4.0\%) & $48(0.3 \%)$ & $41,170(4.0 \%)$ & $672(4.1 \%)$ & 0.134 & 0.344 & 0.389 \\
\hline $\begin{array}{l}\text { Selected nations of } \\
\text { birth }\end{array}$ & 146,545 & 1230 & 732,725 & 11,565 & & & \\
\hline India & $29,744(20.3 \%)$ & 73 (5.9\%) & $148,720(20.3 \%)$ & $2173(18.8 \%)$ & 0.059 & 0.315 & 0.187 \\
\hline Pakistan & 7907 (5.4\%) & $18(1.5 \%)$ & 39,535 (5.4\%) & 435 (3.8\%) & 0.056 & 0.247 & 0.226 \\
\hline Sri Lanka & 10,256 (7.0\%) & 48 (3.9\%) & $51,280(7.0 \%)$ & $893(7.7 \%)$ & 0.093 & 0.343 & 0.270 \\
\hline $\begin{array}{l}\text { China / Hong Kong / } \\
\text { Taiwan }\end{array}$ & $39,886(27.2 \%)$ & $535(43.5 \%)$ & $199,430(27.2 \%)$ & 3679 (31.8\%) & 0.308 & 0.364 & 0.845 \\
\hline Philippines & 16,461 (11.2\%) & $125(7.6 \%)$ & 82,305 (11.2\%) & $1232(10.7 \%)$ & 0.171 & 0.316 & 0.542 \\
\hline Korea & 4194 (2.9\%) & $25(2.0 \%)$ & $20,970(2.9 \%)$ & $239(2.1 \%)$ & 0.145 & 0.249 & 0.585 \\
\hline Iran & $6754(4.6 \%)$ & $40(3.3 \%)$ & $33,770(4.6 \%)$ & 443 (3.8\%) & 0.139 & 0.287 & 0.484 \\
\hline Poland & 5373 (3.7\%) & $83(6.8 \%)$ & 26,865 (3.7\%) & $544(4.7 \%)$ & 0.287 & 0.351 & 0.818 \\
\hline Guyana & 5072 (3.5\%) & $30(2.4 \%)$ & $25,360(3.5 \%)$ & 447 (3.9\%) & 0.116 & 0.333 & 0.349 \\
\hline Jamaica & 5012 (3.4\%) & 65 (5.3\%) & 25,060 (3.4\%) & 427 (3.7\%) & 0.260 & 0.332 & 0.783 \\
\hline $\begin{array}{l}\text { United States of } \\
\text { America }\end{array}$ & 3906 (2.7\%) & $18(1.5 \%)$ & $19,530(2.7 \%)$ & $258(2.2 \%)$ & 0.127 & 0.279 & 0.454 \\
\hline Russia & 4686 (3.2\%) & $70(5.7 \%)$ & $23,430(3.2 \%)$ & $288(2.5 \%)$ & 0.352 & 0.283 & 1.244 \\
\hline United Kingdom & 3734 (2.6\%) & $43(3.5 \%)$ & $18,670(2.6 \%)$ & 299 (2.6\%) & 0.292 & 0.356 & 0.819 \\
\hline Ukraine & 3560 (2.4\%) & $57(4.6 \%)$ & $17,800(2.4 \%)$ & $208(1.8 \%)$ & 0.367 & 0.264 & 1.389 \\
\hline \multicolumn{8}{|l|}{ Males } \\
\hline Overall & 191,792 & 1956 & 958,960 & 18,329 & 0.240 & 0.413 & 0.582 \\
\hline \multicolumn{8}{|l|}{ Age at index date } \\
\hline $40-49$ years & $106,112(55.3 \%)$ & $580(29.7 \%)$ & $530,757(55.3 \%)$ & $4758(26.0 \%)$ & 0.123 & 0.185 & 0.666 \\
\hline 50 - 59 years & 40,062 (20.9\%) & $476(24.3 \%)$ & $200,563(20.9 \%)$ & $4671(25.5 \%)$ & 0.269 & 0.488 & 0.550 \\
\hline $60-69$ years & 31,575 (16.5\%) & $610(31.2 \%)$ & $157,362(16.4 \%)$ & $6237(34.0 \%)$ & 0.486 & 0.906 & 0.536 \\
\hline $70-74$ years & 8070 (4.2\%) & $168(8.6 \%)$ & $40,492(4.2 \%)$ & $1676(9.1 \%)$ & 0.661 & 1.176 & 0.562 \\
\hline$>=75$ years & $5973(3.1 \%)$ & $122(6.2 \%)$ & 29,786 (3.1\%) & 987 (5.4\%) & 0.844 & 1.258 & 0.670 \\
\hline Selected world regions & 187,835 & 1923 & 939,175 & 17,999 & & & \\
\hline
\end{tabular}


Table 2 Crude rates of CRC among immigrants and controls and crude relative rate among immigrants (Continued)

\begin{tabular}{|c|c|c|c|c|c|c|c|}
\hline East Asia and Pacific & $56,546(30.1 \%)$ & $787(40.9 \%)$ & $282,730(30.1 \%)$ & 6209 (34.5\%) & 0.330 & 0.464 & 0.711 \\
\hline $\begin{array}{l}\text { Europe and Central } \\
\text { Asia }\end{array}$ & $32,489(17.3 \%)$ & $570(29.6 \%)$ & $162,445(17.3 \%)$ & 2968 (16.5\%) & 0.386 & 0.377 & 1.024 \\
\hline $\begin{array}{l}\text { Latin America and } \\
\text { the Caribbean }\end{array}$ & $17,474(9.3 \%)$ & $136(7.1 \%)$ & $87,370(9.3 \%)$ & $1591(8.8 \%)$ & 0.174 & 0.385 & 0.452 \\
\hline $\begin{array}{l}\text { Middle East and } \\
\text { North Africa }\end{array}$ & 18,355 (9.8\%) & $164(8.5 \%)$ & $91,775(9.8 \%)$ & $1589(8.8 \%)$ & 0.221 & 0.389 & 0.570 \\
\hline South Asia & $54,756(29.2 \%)$ & $205(10.7 \%)$ & $273,780(29.2 \%)$ & 5025 (27.9\%) & 0.090 & 0.413 & 0.218 \\
\hline Sub-saharan Africa & 8215 (4.4\%) & $61(3.2 \%)$ & $41,075(4.4 \%)$ & 617 (3.4\%) & 0.180 & 0.329 & 0.545 \\
\hline Selected nations of birth & 133,234 & 1341 & 666,170 & 13,209 & & & \\
\hline India & 30,557 (22.9\%) & $98(7.3 \%)$ & $152,785(22.9 \%)$ & 3028 (22.9\%) & 0.079 & 0.450 & 0.177 \\
\hline Pakistan & 10,875 (8.2\%) & $34(2.5 \%)$ & $54,375(8.2 \%)$ & $697(5.3 \%)$ & 0.078 & 0.291 & 0.268 \\
\hline Sri Lanka & 8005 (6.0\%) & $58(4.3 \%)$ & $40,025(6.0 \%)$ & $930(7.0 \%)$ & 0.150 & 0.489 & 0.307 \\
\hline China / Hong Kong / Taiwan & $35,957(27.0 \%)$ & $562(41.9 \%)$ & $179,785(27.0 \%)$ & $4246(32.1 \%)$ & 0.376 & 0.495 & 0.759 \\
\hline Philippines & $11,588(8.7 \%)$ & $115(8.6 \%)$ & $57,940(8.7 \%)$ & $1152(8.7 \%)$ & 0.229 & 0.433 & 0.528 \\
\hline Korea & $4257(3.2 \%)$ & $41(3.1 \%)$ & $21,285(3.2 \%)$ & $252(1.9 \%)$ & 0.234 & 0.255 & 0.920 \\
\hline Iran & $7381(5.5 \%)$ & $86(6.4 \%)$ & $36,905(5.5 \%)$ & $636(4.8 \%)$ & 0.279 & 0.385 & 0.724 \\
\hline Poland & $3343(2.5 \%)$ & $70(5.2 \%)$ & $16,715(2.5 \%)$ & $373(2.8 \%)$ & 0.383 & 0.377 & 1.017 \\
\hline Guyana & $3601(2.7 \%)$ & $31(2.3 \%)$ & $18,005(2.7 \%)$ & $427(3.2 \%)$ & 0.176 & 0.471 & 0.374 \\
\hline Jamaica & $3496(2.6 \%)$ & $31(2.3 \%)$ & $17,480(2.6 \%)$ & $335(2.5 \%)$ & 0.184 & 0.394 & 0.466 \\
\hline $\begin{array}{l}\text { United States of } \\
\text { America }\end{array}$ & $3506(2.6 \%)$ & $28(2.1 \%)$ & $17,530(2.6 \%)$ & $289(2.2 \%)$ & 0.230 & 0.372 & 0.618 \\
\hline Russia & $3662(2.8 \%)$ & $71(5.3 \%)$ & $18,310(2.8 \%)$ & $256(1.9 \%)$ & 0.463 & 0.316 & 1.464 \\
\hline United Kingdom & 4142 (3.1\%) & $62(4.6 \%)$ & $20,710(3.1 \%)$ & $370(2.8 \%)$ & 0.373 & 0.405 & 0.921 \\
\hline Ukraine & 2864 (2.1\%) & $54(4.0 \%)$ & $14,320(2.1 \%)$ & $218(1.7 \%)$ & 0.437 & 0.344 & 1.269 \\
\hline
\end{tabular}

${ }^{a}$ per 100,000 person-years

controls, and log-log plots were used to assess if the hazard functions were proportional. Multivariable extended Cox regression models were then implemented, controlling for baseline characteristics [26]. Note that since we performed exposure-control matching, as opposed to case-control matching, the matched characteristics are permitted in the multivariable model. To account for within-cluster correlation that may arise due to the matched design, a robust sandwich variance estimation approach was used. As it was possible for the association between immigration status and hazard of CRC to change over time, we included an interaction between immigration status (immigrant or non-immigrant) and time, where time was categorized into two intervals using the point of 10 years after index [27]. Analyses were conducted with SAS version 9.3 (SAS Institute, Inc., Cary, NC). All statistical tests were two sided, and $P$ values less than .05 were considered statistically significant.

\section{Results}

We identified 209,843 female immigrants with 2,538,966 person-years of follow-up to death, diagnosis of CRC, or
December 31, 2014, whichever came first. The index date for $84.4 \%$ of female immigrants fell between July 1 , 1991 and December 31, 2005 (i.e. between 9 and 23 years prior to the last available date for records of CRC diagnosis). We matched them to 1,049,215 controls with $13,917,936$ person-years of follow-up. We identified 191,792 male immigrants (for whom the index date fell between July 1, 1991 and December 31, 2005 among $84.7 \%$ ) with 2,228,448 person-years of follow-up and matched them to 958,960 controls with 12,160,208 person-years of follow-up (Table 1). Mean and median duration follow-up of followup are modestly longer for controls compared to immigrants; this is due to higher emigration from Ontario among immigrants compared to controls, rather than higher mortality. The crude relative death rate among immigrants compared to controls is 0.555 per 100,000 person-years, and is lower among all strata of age at index and among all world regions and countries of birth of immigrants (data not shown).

Among female immigrants, 58.2\% had been born in the East Asia and Pacific or the South Asia world regions, and 146,545 / 209,843 (69.8\%) had been born in one of 14 among all 211 represented countries of birth, with $27.2 \%$ 
having been born in China / Hong Kong / Taiwan and $20.3 \%$ in India. Among male immigrants, $59.3 \%$ had been born in the East Asia and Pacific or South Asia world regions, and133,234 / 191,792 (69.5\%) had been born in one of 14 among all 213 represented countries of birth, with 27.0\% having been born in China / Hong Kong / Taiwan and $22.9 \%$ in India (Table 2). Among females, 1877 cases of CRC were observed among immigrants and 16,517 among controls; the crude rate of CRC among female immigrants was 0.203 per 100,000 person-years, compared to 0.325 per 100,000 person-years among female controls, increased by age at index date, and varied by world region and by country of birth Overall, the crude relative rate of $\mathrm{CRC}$ among female immigrants was 0.623 , ranging from 0.233 among those born in South Asia to 1.027 among those born in Europe and Central Asia. The crude relative rate exceeded 1.000 for those born in Russia and Ukraine.
Among males, 1956 cases of CRC were observed among immigrants and 18,329 among controls; the crude rate among immigrants was 0.24 per 100,000 personyears, compared to 0.413 among controls, increased by age at index date, and varied by world region and country of birth. Compared to male controls, the overall crude relative event rate among male immigrants was 0.582. Among world regions, the crude relative rates of CRC for immigrants ranged from 0.218 for those born in South Asia to 1.024 for Europe and Central Asia. The crude relative rate of CRC exceeded 1.000 for those born in Poland, Russia, and Ukraine (Table 2).

By the Kaplan-Meier method, the risk of colorectal cancer diagnosis over time was consistently higher among female controls compared to immigrants in all age strata $(\log$ rank test $p<0.0001$ except for females
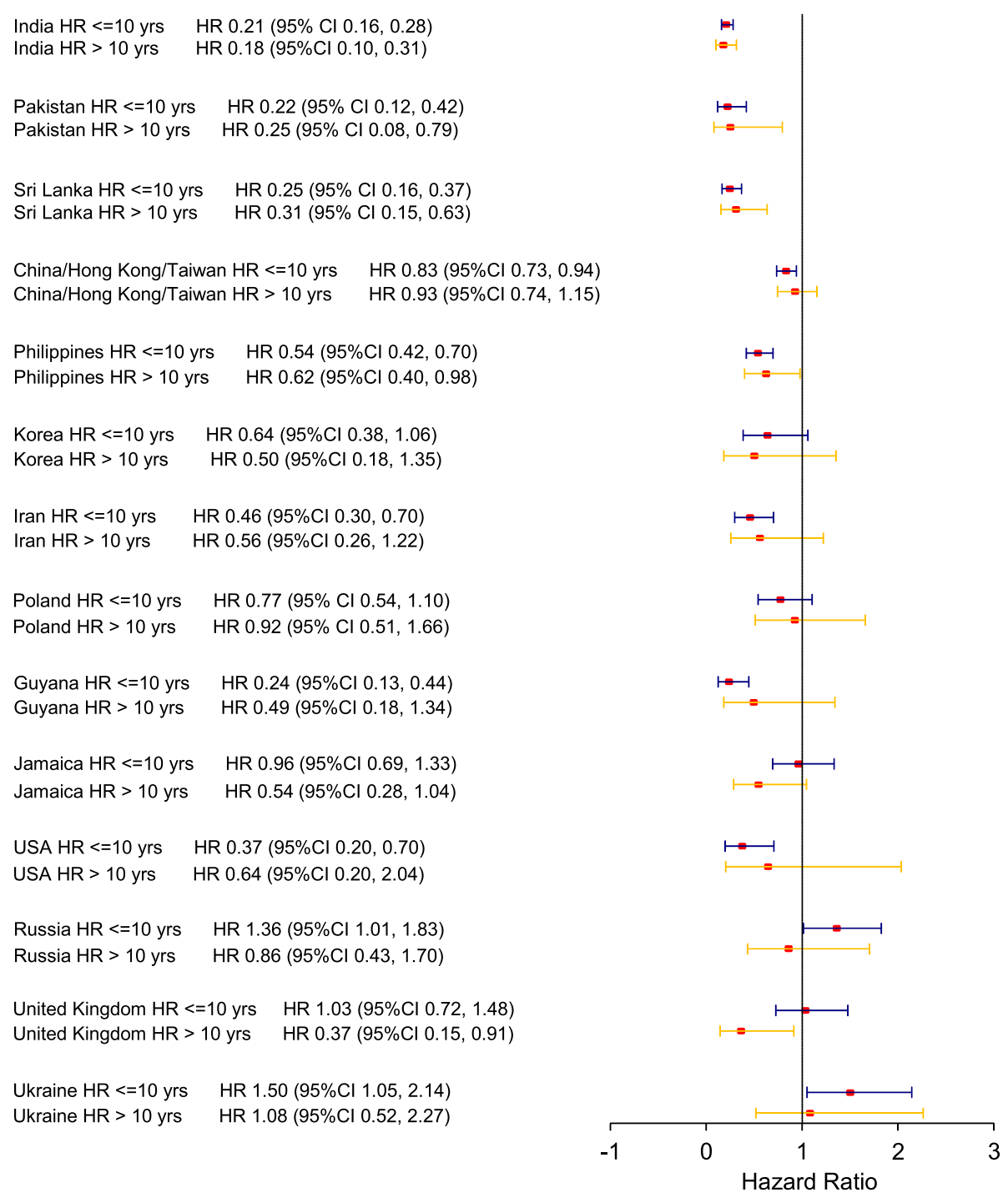

Fig. 1 Forest plot for Adjusted Hazard Ratio for CRC among females by birth country 
$>=75$ years of age, log rank test $p=0.01)$, and among male controls compared to immigrants (log rank test $p<0.0001$ in all age strata). Examination of sex and age stratified log-log plots of time to colorectal cancer demonstrated that the hazards of CRC were proportional in all sex and age strata. (not shown).

The age-adjusted hazard ratio (HR) for CRC among female immigrants was 0.63 (95\% CI $0.59,0.67)$ during the first 10 years after arrival, and 0.66 (95\% CI $0.59,0.74$ ) thereafter. Among male immigrants the age-adjusted $\mathrm{HR}=0.55$ (95\% CI $0.52,0.59)$ during the first 10 years, and $0.63(95 \%$ CI $0.57,0.71)$ thereafter.

The age-adjusted HRs vary among the world regions, and in general are significantly less than 1.00 except among those born in Europe and Central Asia. The point estimates of the age-adjusted HRs $>10$ years after the index date are increased compared to $<=10$ years for some regions and the respective 95\% confidence intervals include unity. Figures 1 and 2 display forest plots of the stratified age-adjusted HRs for CRC for the 14 countries of birth with the largest number of immigrants, for females and males respectively. There are greater differences in age-adjusted HRs among these 14 countries of birth compared to those among the seven world regions of birth in Table 3.

\section{Discussion}

The risk of CRC among immigrants who arrived in Ontario at the age of 40 years or older, between 1991 and 2008 , is lower overall compared to age-matched controls for more than 10 years after immigration. Their risk varies among world regions of birth, and among the 14 countries in which the majority of immigrants were born. All arrived in Ontario prior to the inception of the CCC screening

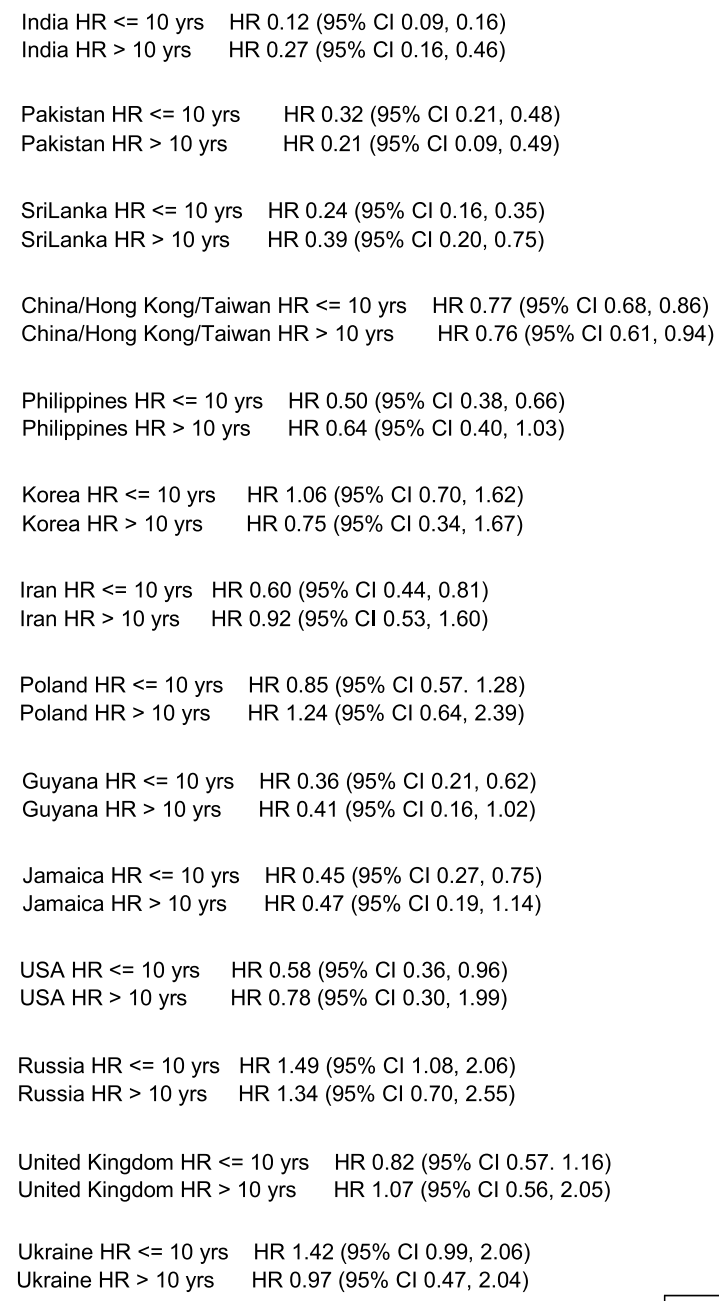

Fig. 2 Forest plot for Adjusted Hazard Ratio for CRC among males by birth country 
Table 3 Adjusted cox models of CRC risk stratified by sex

\begin{tabular}{|c|c|c|c|c|c|c|}
\hline \multirow[t]{2}{*}{ Variable } & \multicolumn{3}{|l|}{ Females } & \multicolumn{3}{|l|}{ Males } \\
\hline & $\begin{array}{l}\text { Univariate HR } \\
(95 \% \mathrm{Cl})\end{array}$ & $\begin{array}{l}\text { Multivariate HR } \\
(95 \% \mathrm{Cl})\end{array}$ & $\begin{array}{l}\text { Multivariate HR } \\
(95 \% \mathrm{Cl}) \text { with } \\
\text { interaction }\end{array}$ & $\begin{array}{l}\text { Univariate HR } \\
(95 \% \mathrm{Cl})\end{array}$ & $\begin{array}{l}\text { Multivariate HR } \\
(95 \% \mathrm{Cl})\end{array}$ & $\begin{array}{l}\text { Multivariate HR } \\
(95 \% \mathrm{Cl}) \text { with } \\
\text { interaction }\end{array}$ \\
\hline \multicolumn{7}{|l|}{ Overall } \\
\hline Immigrant & $0.63(0.60,0.66)$ & $0.64(0.61,0.67)$ & & $0.59(0.56,0.62)$ & $0.59(0.56,0.62)$ & \\
\hline Nonimmigrant controls & Reference & Reference & & Reference & Reference & \\
\hline \multicolumn{7}{|l|}{ Age at index } \\
\hline $40-49$ & Reference & Reference & Reference & Reference & Reference & Reference \\
\hline $50-59$ & $2.35(2.25,2.45)$ & $2.35(2.25,2.45)$ & $2.35(2.25,2.45)$ & $2.59(2.50,2.70)$ & $2.60(2.50,2.70)$ & $2.60(2.50,2.70)$ \\
\hline $60-69$ & $4.54(4.36,4.73)$ & $4.53(4.35,4.72)$ & $4.53(4.35,4.72)$ & $4.94(4.77,5.12)$ & $4.94(4.77,5.12)$ & $4.94(4.77,5.12)$ \\
\hline $70-74$ & $6.54(6.19,6.91)$ & $6.52(6.17,6.88)$ & $6.52(6.17,6.88)$ & $6.99(6.62,7.37)$ & $6.98(6.62,7.37)$ & $6.98(6.62,7.37)$ \\
\hline$>=75$ & $8.63(8.11,9.17)$ & $8.63(8.12,9,17)$ & $8.63(8.12,9.17)$ & $8.46(7.93,9.03)$ & $8.47(7.94,9.04)$ & $8.47(7.94,9.04)$ \\
\hline $\begin{array}{l}\text { Immigrant }<=10 \text { years } \\
\text { since index date }\end{array}$ & $0.62(0.58,0.66)$ & & $0.63(0.59,0.67)$ & $0.55(0.52,0.59)$ & & $0.55(0.52,0.59)$ \\
\hline $\begin{array}{l}\text { Controls }<=10 \text { years since } \\
\text { index date }\end{array}$ & Reference & & Reference & Reference & & Reference \\
\hline $\begin{array}{l}\text { Immigrant }>10 \text { years } \\
\text { since index date }\end{array}$ & $0.65(0.58,0.73)$ & & $0.66(0.59,0.74)$ & $0.64(0.57,0.72)$ & & $0.63(0.57,0.71)$ \\
\hline $\begin{array}{l}\text { Controls }<=10 \text { years since } \\
\text { index date }\end{array}$ & Reference & & Reference & Reference & & Reference \\
\hline \multicolumn{7}{|l|}{$\begin{array}{l}\text { Age adjusted models for } \\
\text { world region of birth }\end{array}$} \\
\hline \multicolumn{7}{|l|}{ East Asia and Pacific } \\
\hline $\begin{array}{l}\text { Immigrant }<=10 \\
\text { years since index date }\end{array}$ & $0.70(0.63,0.78)$ & & $0.72(0.65,0.80)$ & $0.70(0.64,0.78)$ & & $0.72(0.65,0.79)$ \\
\hline $\begin{array}{l}\text { Controls }<=10 \text { years } \\
\text { since index date }\end{array}$ & Reference & & Reference & Reference & & Reference \\
\hline $\begin{array}{l}\text { Immigrant }>10 \\
\text { years since index date }\end{array}$ & $0.79(0.66,0.95)$ & & $0.80(0.67,0.96)$ & $0.74(0.62,0.89)$ & & $0.73(0.61,0.87)$ \\
\hline $\begin{array}{l}\text { Controls }<=10 \text { years } \\
\text { since index date }\end{array}$ & Reference & & Reference & Reference & & Reference \\
\hline \multicolumn{7}{|l|}{ Europe and Central Asia } \\
\hline $\begin{array}{l}\text { Immigrant }<=10 \\
\text { years since index date }\end{array}$ & $1.10(0.98,1.23)$ & & $1.09(0.97,1.22)$ & $1.02(0.90,1.15)$ & & $1.01(0.90,1.14)$ \\
\hline $\begin{array}{l}\text { Controls }<=10 \text { years } \\
\text { since index date }\end{array}$ & Reference & & Reference & Reference & & Reference \\
\hline $\begin{array}{l}\text { Immigrant }>10 \text { years } \\
\text { since index date }\end{array}$ & $0.96(0.77,1.18)$ & & $0.96(0.78,1.19)$ & $1.05(0.85,1.30)$ & & $1.04(0.84,1.29)$ \\
\hline $\begin{array}{l}\text { Controls }<=10 \text { years } \\
\text { since index date }\end{array}$ & Reference & & Reference & Reference & & Reference \\
\hline \multicolumn{7}{|l|}{$\begin{array}{l}\text { Latin America and the } \\
\text { Caribbean }\end{array}$} \\
\hline $\begin{array}{l}\text { Immigrant }<=10 \\
\text { years since index date }\end{array}$ & $0.58(0.47,0.71)$ & & $0.59(0.48,0.72)$ & $0.45(0.35,0.57)$ & & $0.46(0.36,0.58)$ \\
\hline $\begin{array}{l}\text { Controls }<=10 \text { years } \\
\text { since index date }\end{array}$ & Reference & & Reference & Reference & & Reference \\
\hline $\begin{array}{l}\text { Immigrant }>10 \text { years } \\
\text { since index date }\end{array}$ & $0.56(0.39,0.81)$ & & $0.58(0.41,0.84)$ & $0.46(0.30,0.71)$ & & $0.46(0.30,0.71)$ \\
\hline $\begin{array}{l}\text { Controls }<=10 \text { years } \\
\text { since index date }\end{array}$ & Reference & & Reference & Reference & & Reference \\
\hline $\begin{array}{l}\text { Middle East and North } \\
\text { Africa }\end{array}$ & & & & & & \\
\hline
\end{tabular}


Table 3 Adjusted cox models of CRC risk stratified by sex (Continued)

\begin{tabular}{|c|c|c|c|c|}
\hline $\begin{array}{l}\text { Immigrant }<=10 \\
\text { years since index date }\end{array}$ & $0.52(0.40,0.67)$ & $0.52(0.40,0.68)$ & $0.49(0.39,0.61)$ & $0.48(0.38,0.60)$ \\
\hline $\begin{array}{l}\text { Controls }<=10 \text { years } \\
\text { since index date }\end{array}$ & Reference & Reference & Reference & Reference \\
\hline $\begin{array}{l}\text { Immigrant }>10 \text { years } \\
\text { since index date }\end{array}$ & $0.54(0.33,0.87)$ & $0.54(0.34,0.88)$ & $0.72(0.49,1.07)$ & $0.70(0.47,1.03)$ \\
\hline $\begin{array}{l}\text { Controls }<=10 \text { years } \\
\text { since index date }\end{array}$ & Reference & Reference & Reference & Reference \\
\hline \multicolumn{5}{|l|}{ South Asia } \\
\hline $\begin{array}{l}\text { Immigrant }<=10 \\
\text { years since index date }\end{array}$ & $0.23(0.19,0.28)$ & $0.24(0.19,0.29)$ & $0.17(0.14,0.21)$ & $0.18(0.14,0.22)$ \\
\hline $\begin{array}{l}\text { Controls }<=10 \text { years } \\
\text { since index date }\end{array}$ & Reference & Reference & Reference & Reference \\
\hline $\begin{array}{l}\text { Immigrant }>10 \text { years } \\
\text { since index date }\end{array}$ & $0.24(0.17,0.35)$ & $0.25(0.17,0.37)$ & $0.28(0.20,0.40)$ & $0.28(0.20,0.40)$ \\
\hline $\begin{array}{l}\text { Controls }<=10 \text { years } \\
\text { since index date }\end{array}$ & Reference & Reference & Reference & Reference \\
\hline \multicolumn{5}{|l|}{ Sub-saharan Africa } \\
\hline $\begin{array}{l}\text { Immigrant }<=10 \\
\text { years since index date }\end{array}$ & $0.27(0.17,0.43)$ & $0.27(0.17,0.43)$ & $0.39(0.26,0.59)$ & $0.38(0.25,0.57)$ \\
\hline $\begin{array}{l}\text { Controls }<=10 \text { years } \\
\text { since index date }\end{array}$ & Reference & Reference & Reference & Reference \\
\hline $\begin{array}{l}\text { Immigrant }>10 \text { years } \\
\text { since index date }\end{array}$ & $0.56(0.26,1.18)$ & $0.56(0.26,1.18)$ & $0.78(0.40,1.53)$ & $0.75(0.38,1.48)$ \\
\hline $\begin{array}{l}\text { Controls }<=10 \text { years } \\
\text { since index date }\end{array}$ & Reference & Reference & Reference & Reference \\
\hline
\end{tabular}

program and many of those diagnosed with $\mathrm{CRC}$ received the diagnosis prior to its inception. It is already known that immigrants to Ontario are less likely to participate in CRC screening [18]. In its future efforts to improve participation in CRC screening by immigrants, CCC should include tailored approaches to the sizable numbers of immigrants from countries of birth for which the ageadjusted risks of CRC are close to, or equivalent to, those of the non-immigrant controls.

This is an important study comprising a large population of 401,635 immigrants from 213 countries. The available data elements are appropriate for a time-toevent analytic approach, that is more powerful and illuminating than crude rates and incidence ratios, and it was possible to examine the potential interaction between status as an immigrant and time since immigration. Prior studies of the risk of CRC among immigrants have substantial weaknesses compared to this work. A national study among immigrants to Canada from 1980 to 1990, using probabilistic rather than deterministic linkage, with followup for CRC among other cancer types to 1998, had fewer immigrants despite being nation-wide, $90.8 \%$ of whom were $<=44$ years of age at the time of immigration [11]. The young age distribution is reflected in the low number of cases of CRC observed among immigrants ( $n=71$ compared to $n=3833)$; the low number of cases prevented the use of time to event analytic methods and stratification by country of birth. Other Canadian studies of small numbers of immigrants were unable to use to time to event methods and did not examine the worldwide distribution of origin of immigrants $[12,28]$. Studies from the US [13] and the UK [14] examined relative rates between immigrants from a limited number of origins.

A limitation of the study is the inability to match immigrants to controls on comorbidity or past medical history on the matching date. Although immigrants and controls hypothetically could be linked to census-level ecologic measures of socio-economic status by postal code on the matching date, we doubt that those measures at the time of the arrival of immigrants in Ontario would be valid descriptors of socio-economic influences on the health of the immigrants up to the time of their arrival. A further limitation is the lack of data about the risks of CRC beyond two decades since arrival, which might plausbility increase as observed among certain ethnic groups in California [9]. We are unable to comment on the association of colorectal screening with immigration status, or the association between colorectal screening among immigrants and their risk of colorectal 
cancer in this study, because the population-based CRC screening programme in Ontario was introduced near the end of the observation period.

The variability of the risk of CRC among immigrants to Ontario relative to controls, by region or country of origin, has implications for colorectal screening in Ontario. Efforts to improve screening participation among immigrants may be tailored by this information. Furthermore, the risk of CRC should be monitored during the period beyond two decades since arrival.

\section{Conclusions}

The risk of CRC among immigrants to Ontario varies by length of time residing in Ontario and birthplace, and, with the exception of those born in the Europe andCentral Asia region, and in the individual countries of Russia and Ukraine, is lower than that for non-immigrants for up to two decades after arrival.

\section{Abbreviations \\ CCC: Colon Cancer Check; Cl: Confidence interval; CRC: Colorectal cancer; HR: Hazard ratio; ICES: Institute for Clinical Evaluative Sciences; \\ IRCC: Immigration, Refugees and Citizenship Canada; OCR: Ontario Cancer Registry; OHIP: Ontario Health Insurance Plan}

\section{Acknowledgements}

This study is based on data and information from the Government of Canada (Immigration, Refugees and Citizenship Canada (IRCC)'s Permanent Resident Database), the Ministry of Health and Long Term Care of Ontario (RPDB and OHIP), and Cancer Care Ontario (OCR). The opinions, results, view, and conclusions reported in this paper are those of the authors and do not necessarily reflect those of the Government of Canada, the Ministry of Health and Long Term Care of Ontario or Cancer Care Ontario. No endorsement by the Government of Canada, the Ministry of Health and Long Term Care of Ontario, or Cancer Care Ontario is intended or should be inferred.

\section{Funding}

This work was funded by an Applied Cancer Research Unit grant from Cancer Care Ontario to Lawrence Paszat. Cancer Care Ontario had no role in the design of the study and collection, analysis, and interpretation of data and in writing the manuscript. This study was supported by the Institute for Clinical Evaluative Sciences (ICES), which is funded by an annual grant from the Ontario Ministry of Health and Long-Term Care (MOHLTC).

\section{Availability of data and materials}

The data set from this study is held securely in coded form at the Institute for Clinical Evaluative Sciences (ICES). While data sharing agreements prohibit ICES from making the data set publicly available, access may be granted to those who meet pre-specified criteria for confidential access (www.ices.on.ca/DAS). The full data set creation plan is available from the authors upon request. The data that support the findings of this study are available from the Government of Canada (Immigration, Refugees and Citizenship Canada Permanent Resident Database), the Ontario Ministry of Health and Long Term Care (Ontario Health Insurance Plan and Registered Person's Database), and Cancer Care Ontario (Ontario Cancer Registry) but restrictions apply to the availability of these data, which were used under license for the current study, and so are not publicly available. Data are however available from the Government of Canada, the Ontario Ministry of Health and Long Term Care, and Cancer Care Ontario respectively, to qualified and approved investigators.

\section{Authors' contributions}

This research was designed by LP, RS, NB, JT and LR. The data were extracted and analyzed by $Y L$ under the supervision of $L P$ and $R S$. The data were interpreted by LP, RS, NB, JT and LR. The manuscript was drafted by LP. All authors read and approved the final manuscript.

\section{Ethics approval and consent to participate}

This research was approved by the Research Ethics Board of Sunnybrook Health Sciences Centre. All data had been previously stripped of personal identifiers so that consent to participate was not required.

\section{Consent for publication}

Not applicable.

Competing interests

The authors declare that they have no competing interests.

\section{Publisher's Note}

Springer Nature remains neutral with regard to jurisdictional claims in published maps and institutional affiliations.

\section{Author details}

${ }^{1}$ University of Toronto, Institute for Clinical Evaluative Sciences, G106 2075 Bayview Avenue, Toronto, ON M4N3M5, Canada. ${ }^{2}$ University of Toronto, St Michael's Hospital, 30 Bond Street, Toronto, ON M5B1W8, Canada. ${ }^{3}$ University of Toronto, Sunnybrook Health Sciences Centre, 2075 Bayview Avenue, Toronto, ON M4N3M5, Canada. ${ }^{4}$ University of Toronto, Prevention and Cancer Control, Cancer Care Ontario, 620 University Avenue, Toronto, ON M4, Canada.

Received: 3 March 2017 Accepted: 29 June 2017

Published online: 06 July 2017

\section{References}

1. Favoriti P, Carbone G, Greco M, Pirozzi F, Pirozzi RE, Corcione F. Worldwide burden of colorectal cancer: a review. Updates Surg. 2016;68(1):7-11.

2. Jemal A, Center MM, DeSantis C, Ward EM. Global patterns of cancer incidence and mortality rates and trends. Cancer Epidemiol Biomark Prev. 2010;19(8):1893-907.

3. Marley AR, Nan H. Epidemiology of colorectal cancer. Int J Mol Epidemiol Genet. 2016;7(3):105-14.

4. Bishehsari F, Mahdavinia M, Vacca M, Malekzadeh R, Mariani-Costantini R. Epidemiological transition of colorectal cancer in developing countries: environmental factors, molecular pathways, and opportunities for prevention. World J Gastroenterol. 2014;20(20):6055-72.

5. Center MM, Jemal A, Ward E. International trends in colorectal cancer incidence rates. Cancer Epidemiol Biomark Prev. 2009;18(6):1688-94.

6. Dolatkhah R, Somi MH, Kermani IA, Ghojazadeh M, Jafarabadi MA, Farassati F, Dastgiri S. Increased colorectal cancer incidence in Iran: a systematic review and meta-analysis. BMC Public Health. 2015;15:997.

7. Sung JJ, Lau JY, Goh KL. Leung WK; Asia Pacific working group on colorectal cancer. Increasing incidence of colorectal cancer in Asia: implications for screening. Lancet Oncol. 2005:6(11):871-6.

8. Pathy S, Lambert R, Sauvaget C, Sankaranarayanan R. The incidence and survival rates of colorectal cancer in India remain low compared with rising rates in East Asia. Dis Colon Rectum. 2012;55(8):900-6.

9. Giddings BH, Kwong SL, Parikh-Patel A, Bates JH, Snipes KP. Going against the tide: increasing incidence of colorectal cancer among Koreans, Filipinos, and south Asians in California, 1988-2007. Cancer Causes Control. 2012;23(5):691-702.

10. International Agency for Cancer Research, World Health Organization. The Global Cancer Atlas. https://gco.iarc.fr/today/. Accessed 23 Jan 2017.

11. McDermott S, Desmeules M, Lewis R, Gold J, Payne J, Lafrance B, Vissandjée B, Kliewer E, Mao Y. Cancer incidence among Canadian immigrants, 1980-1998: results from a national cohort study. J Immigr Minor Health. 2011;13(1):15-26.

12. Virk R, Gill S, Yoshida E, Radley S, Salh B. Racial differences in the incidence of colorectal cancer. Can J Gastroenterol. 2010;24(1):47-51.

13. Wu X, Chen WW, Martin J, Roffers S, Groves FD, Correa CN, Hamilton-Byrd E, Jemal A. Subsite-specific colorectal cancer incidence rates and stage distributions among Asians and Pacific islanders in the United States, 1995 to 1999. Cancer Epidemiol Biomark Prev. 2004;13(7):1215-22.

14. Hebbar S, Fuggle WJ, Nevill AM, Veitch AM. Colorectal cancer incidence and trend in UK south Asians: a 20-year study. Color Dis. 2012;14(6):e319-22.

15. Rabeneck L, Tinmouth JM, Paszat LF, Baxter NN, Marrett LD, Ruco A, Lewis N, Gao J. Ontario's ColonCancerCheck: results from canada's first province- 
wide colorectal cancer screening program. Cancer Epidemiol Biomark Prev. 2014;23(3):508-15.

16. Cotterchio M, Manno M, Klar N, McLaughlin J, Gallinger S. Colorectal screening is associated with reduced colorectal cancer risk: a case-control study within the population-based Ontario familial colorectal cancer registry. Cancer Causes Control. 2005;16(7):865-75.

17. Goede SL, Rabeneck L, Lansdorp-Vogelaar I, Zauber AG, Paszat LF, Hoch JS, Yong JH, van Hees F, Tinmouth J, van Ballegooijen M. The impact of stratifying by family history in colorectal cancer screening programs. Int J Cancer. 2015;137(5):1119-27.

18. Buchman S, Rozmovits L, Glazier RH. Equity and practice issues in colorectal cancer screening: mixed-methods study. Can Fam Physician. 2016;62(4):e186-93.

19. Decker KM, Singh H. Reducing inequities in colorectal cancer screening in North America. J Carcinog. 2014;13:12. doi:10.4103/1477-3163.

20. Kim K, Chandrasekar E, Lam H. Colorectal cancer screening among Chinese, Cambodian, and Vietnamese immigrants in Chicago. J Racial Ethn Health Disparities. 2015;2(4):473-80. doi:10.1007/s40615-015-0095-x.

21. Idowu KA, Adenuga B, Otubu O, Narasimhan K, Kamara F, HunterRichardson F, Larbi D, Sherif ZA, Laiyemo AO. Place of birth, cancer beliefs and being current with colon cancer screening among US adults. Ann Gastroenterol. 2016;29(3):336-40. doi: 10.20524/aog.2016.0040.

22. Turrin A, Zorzi M, Giorgi Rossi P, Senore C, Campari C, Fedato C, Naldoni C, Anghinoni E, Carrozzi G. Sassoli De' Bianchi P, Zappa M; Italian colorectal cancer screening survey group. Colorectal cancer screening of immigrants to Italy. Figures from the 2013 national survey. Prev Med. 2015;81:132-7. doi: 10.1016/j.ypmed.2015.08.016.

23. Lofters AK, Moineddin R, Hwang SW, Glazier RH. Predictors of low cervical cancer screening among immigrant women in Ontario, Canada. BMC Womens Health. 2011:11-20.

24. Lofters AK, Hwang SW, Moineddin R, Glazier RH. Cervical cancer screening among urban immigrants by region of origin: a population-based cohort study. Prev Med. 2010;51(6):509-16.

25. Creatore MI, Booth GL, Manuel DG, Moineddin R, Glazier RH. Diabetes screening among immigrants: a population-based urban cohort study. Diabetes Care. 2012;35(4):754-61.

26. Therneau T. Modelling survival data: extending the Cox model. New York: Springer; 2000.

27. Allison PD. Survival analysis using SAS: a practical guide SAS Institute; 1995.

28. Sheth T, Nair C, Nargundkar M, Anand S, Yusuf S. Cardiovascular and cancer mortality among Canadians of European, south Asian and Chinese origin from 1979 to 1993: an analysis of 1.2 million deaths. CMAJ. 1999;161(2):132-8.

\section{Submit your next manuscript to BioMed Central and we will help you at every step:}

- We accept pre-submission inquiries

- Our selector tool helps you to find the most relevant journal

- We provide round the clock customer support

- Convenient online submission

- Thorough peer review

- Inclusion in PubMed and all major indexing services

- Maximum visibility for your research

Submit your manuscript at www.biomedcentral.com/submit 